\title{
EVALUATION OF ANTI-ULCER ACTIVITY OF AQUEOUS EXTRACT OF BLACK CUMIN SEEDS (NIGELLA SATIVA L) ON EXPERIMENTAL ALBINO RATS
}

\author{
${ }^{*}$ Sengupta Mohua ${ }^{1}$, Mondal Palash, ${ }^{2}$ Saha (Das) Mita ${ }^{3}$, Paul Suhrita ${ }^{4}$, Gupta Mradu ${ }^{5}$ \\ ${ }^{1}$ M.D. Assistant Professor, Dept. of Pharmacology, Medical College, Kolkata \\ ${ }^{2}$ M.D. Associate Professor, Dept. of Pathology,North Bengal Medical College,W.B \\ ${ }^{3}$ M.D. Associate Professor, Dept. of Biochemistry, R.G.Kar Medical College, Kolkata \\ ${ }^{4}$ M.D. Professor, Dept. of Pharmacology, Medical College, Kolkata \\ ${ }^{5} \mathrm{MD}$ (Ayurveda), PhD. Reader, Dept. of Dravyaguna, IPGAER, Kolkata \\ *Corresponding Author's E-Mail: senguptamohua@yahoo.co.in
}

Received 14 Dec 2012; Review Completed 30 Dec 2012; Accepted 09 Jan 2013, Available online 15 Jan 2013

\begin{abstract}
:
Seeds of Nigella sativa L. (Rananculacene) or Black cumin seed is widely used in the Indian subcontinent in treatment of gastric ulcer as a traditional medicine. In this present study, our aim was to investigate gastro-protective activity of aqueous extract of black cumin seeds in aspirin induced ulcer models in albino rats taking ranitidine as positive control. Albino rats of Wistar strain, (150-200 g) was divided randomly into four groups $(\mathrm{n}=6)$ and received the following medications orally for five days. Group A $-1 \%$ gum acacia $5 \mathrm{ml} / \mathrm{kg}$, Group B and Group C- aqueous extract of Black Cumin $250 \mathrm{mg} / \mathrm{kg}$ and $500 \mathrm{mg} / \mathrm{kg}$ body wt respectively and Group D - Ranitidine $20 \mathrm{mg} /$ $\mathrm{kg}$ body wt; followed by aspirin $200 \mathrm{mg} / \mathrm{kg}$ body wt administered orally on $6^{\text {th }}$ day to all groups after 24 hours of fasting. Animals were sacrificed after 4 hours of pyloric ligation. The stomachs were removed. The gastric contents were evaluated by biochemical parameters and gastric ulceration was studied by comparing the volume of gastric juice, free acidity, total acidity, ulcer index and by histopathological study.Statistical analysis was done using one way ANOVA and Tukey Kramer Multiple Comparison Test.The present study infers that aqueous extract of N. Sativa in doses $250 \mathrm{mg} / \mathrm{kg}$ and $500 \mathrm{mg} / \mathrm{kg}$ reduced volume of gastric juice, free and total acidity and ulcer index in a highly significant manner when compared to control $(\mathrm{p}<0.001)$. N.sativa $(500 \mathrm{mg} / \mathrm{kg})$ dose proved to be comparable ( $>>0.05$ ) to positive control (ranitidine $20 \mathrm{mg} / \mathrm{kg}$ ), while $\mathrm{N}$. sativa $250 \mathrm{mg} / \mathrm{kg}$ proved to be less effective than its higher dose and ranitidine $(\mathrm{p}<0.01)$. The results were expressed as mean $\pm \mathrm{SEM}$. Thus aqueous extract of NS $(500 \mathrm{mg} / \mathrm{kg})$ has potent gastro protective properties comparable to Ranitidine $20 \mathrm{mg} / \mathrm{kg}$
\end{abstract}

Key Words: Black cumin, Nigella sativa (Ns), antiulcer.

\section{INTRODUCTION:}

Peptic Ulcer Disease is believed to be due to an imbalance between aggressive and protective factors in the stomach. ${ }^{1}$ Drug treatment of peptic ulcers is targeted at either counteracting aggressive factors (acid, pepsin, active oxidants, platelet aggravating factor "PAF," leukotrienes, endothelins, bile or exogenous factors including NSAIDs) or stimulating the mucosal defences (mucus, bicarbonate, normal blood flow, prostaglandins, nitric oxide). ${ }^{2}$ The goals of treating peptic ulcer disease are to relieve pain, heal the ulcer and prevent ulcer recurrence. Currently, there is no cost-effective treatment that meets all these goals. Hence efforts are on to find a suitable treatment from natural product sources. A large percentage of world population, especially in the developing countries, relies on natural remedies to treat a variety of diseases. So a large number of spices and herbs have been evaluated by various researchers for their anti-ulcer effects. ${ }^{3}$ Seeds of Nigella sativa $L$ (Rananculacene) (NS) contains more than $30 \%$ of a fixed oil and $0.40-0.45 \mathrm{w} / \mathrm{w}$ of a volatile oil. The volatile oil has been shown to contain $18-24 \%$ thymoquinone (TQ) and $46 \%$ monoterpenes. Recent clinical and experimental studies have shown several therapeutic effects of NS extracts including its antioxidant hepatoprotective, immunomodulatory, antiinflammatory and anti-tumor activities. Recently the active principle of NS oil TQ has shown to possess a gastroprotective activity in rats ${ }^{4}$ but few studies have been done to find the ulcer protective activity of aqueous extract of the seeds of N. sativa (black cumin) Therefore, the aim of this study was to evaluate the protective role of aqueous extract of the seeds of N. sativa (black cumin) on ulceration induced by aspirin on albino rats.

\section{MATERIALS AND METHODS:}

\section{Animals}

Albino rats of Wistar strain, of either sex, age 3 months, weighing between 150-200 $\mathrm{g}$ were used. The rats were kept in a room temperature of $22 \pm 3^{\circ} \mathrm{C}$ and 12 -h natural light dark cycle, in the animal house, Department of Pharmacology, Medical College, Kolkata. Rats were fed on standard laboratory feed and water ad libitum. A total of 30 animals were used. All experimental procedures were approved by the Institutional Animal Ethics Committee of Post Graduate Institute of Ayurveda, Kolkata.

\section{Plant material:}

Nigella sativa seeds were purchased from a local herb dealer, identified under expert guidance and preserved for future 
reference. The seeds were dried and ground to a very fine powder and stored in air tight container.

\section{Preparation of extract:}

The powder obtained was soaked in distilled water for 24 hours in percolator. After 24 hours it was allowed to percolate slowly and extract was collected in Petri dishes. ${ }^{5}$ The extract was concentrated in vaccum using rotary flash evaporator and the extract was suspended in $1 \%$ gum acacia as vehicle in this experiment. The dose was selected as $250 \mathrm{mg} / \mathrm{kg}$ and $500 \mathrm{mg} / \mathrm{kg}$ according to previous studies. ${ }^{6}$

\section{Drug procurement:}

Aspirin was obtained from SD Pharmaceuticals; ranitidine was obtained from Ranbaxy Laboratories. The drugs were suspended in $1 \%$ gum acacia in distilled water. The drug suspension and control (1\% gum acacia) were administered at the uniform volume of $1 \mathrm{ml} / \mathrm{kg}$ body weight.

\section{Experimental Procedure:}

Albino rats of Wistar strain, (150-200 g) was divided randomly into four groups $(\mathrm{n}=6)$ and received the following medications orally for five days. Dose of aspirin $(200 \mathrm{mg} / \mathrm{kg})$ and ranitidine $(20 \mathrm{mg} / \mathrm{kg})^{7}$

Group A - $1 \%$ gum acacia $5 \mathrm{ml} / \mathrm{kg}$;

Group B - Ranitidine $20 \mathrm{mg} / \mathrm{kg}$ body wt; body wt

Group C - aqueous extract of Black Cumin $250 \mathrm{mg} / \mathrm{kg}$ body wt

Group D - aqueous extract of Black Cumin $500 \mathrm{mg} / \mathrm{kg}$

All treatments were administered orally for 5 days and on the fifth day, food was withdrawn though water was allowed $a d$ libitum. On sixth day, all rats received aspirin $(200 \mathrm{mg} / \mathrm{kg})$ to induce gastric ulcer. After one hour, pylorus was ligated under light ether anaesthesia (Shay $H$ et al 1945) ${ }^{8}$. Four hours later the animals were sacrificed by cervical dislocation, the stomachs were removed, and opened along the greater curvature. Stomach was gently rinsed with water to remove gastric contents and blood. The gastric contents were evaluated by biochemical parameters and gastric ulceration was studied by comparing the volume of gastric juice, free acidity, total acidity, ulcer index and by histopathological study.

\section{Collection of gastric juice}

After removal of the stomach, the gastric content was collected in a graduated test tube for physical examination. The contents were then centrifuged at 2000 revolutions per minute $(\mathrm{rpm})$ for 10 minutes. The supernatant fluid was subjected to biochemical analysis. ${ }^{9}$

\section{Determination of anti-secretory activity}

To determine anti-secretory activity, the supernatant fluid was analysed for titratable acidity against $0.01 \mathrm{~N} \mathrm{NaOH}$ at pH 7 and the total acid output was calculated.

Free and total acidity: Amount of $0.01 \mathrm{~N} \mathrm{NaOH}$ required to titrate to the methyl yellow end point is the measure of the free acid present. The amount of $0.01 \mathrm{~N} \mathrm{NaOH}$ required to titrate from the beginning to the phenolphthalein end point, is a measure of the total acid present in the sample. ${ }^{10}$ Acidity (mEq/L/100mg) can be expressed as:

$$
\text { Acidity }=\begin{gathered}
\text { Vol. of } \mathrm{NaOH} \times \text { Normality } x 100 \\
0.1
\end{gathered} \quad(\mathrm{mEq} / \mathrm{L} / 100 \mathrm{mg})
$$

\section{Ulcer index}

Stomach was cut along the greater curvature, washed and placed on a card board and ulcer index was counted from the glandular portion. Each lesion was measured along the greatest length and evaluated singly according to their dimensions and severity (area of glandular portion of stomach / area of ulceration in $\mathrm{mm}^{2}$ scale). Ulcer index = $10 / x ;(x=$ area of glandular portion of stomach / area of ulceration in $\mathrm{mm}^{2}$ scale). ${ }^{11}$

\section{Histopathological evaluation}

The gastric tissue samples were fixed in neutral buffered formalin for $24 \mathrm{~h}$. The tissues were processed according to the standard procedure and sections were cut stained with haematoxylin and eosin Bancroft ${ }^{12}$ The slides were examined microscopically for morphological changes such as congestion, haemorrhage, oedema and erosions using an arbitrary scale for the assessment of severity of these changes. $^{13}$

\section{Statistical analysis}

For all the above methods, the results were expressed as Mean \pm SEM. Statistical analysis was done using one way ANOVA test followed by Tukey Kramer multiple comparison test to compare the volume of gastric juice, , free acidity, total acidity, ulcer index, in between the test groups. A "p" value less than 0.05 was considered significant and less than 0.001 was considered highly significant.

\section{RESULTS:}

The results of this study show that oral administration of an aqueous extract of NS prevents gastric mucosal injuries caused by aspirin, the most commonly employed test in the evaluation of anti-ulcer and cytoprotective activities. Biochemical parameters like volume of gastric juice, free acidity, total acidity and ulcer index were noted in all the four groups respectively 
Table 1

\begin{tabular}{|c|c|c|c|c|}
\hline $\begin{array}{c}\text { Biochemical } \\
\text { Parameters. }\end{array}$ & $\begin{array}{c}\text { Group A } \\
\text { 1\%gum acacia }\end{array}$ & $\begin{array}{c}\text { Group B } \\
\text { N. sativa } \\
(250 \mathrm{mg} / \mathrm{Kg})\end{array}$ & $\begin{array}{c}\text { Group C } \\
\text { N. sativa } \\
(500 \mathrm{mg} / \mathrm{Kg})\end{array}$ & $\begin{array}{c}\text { Group D } \\
\text { Ranitidine } \\
(20 \mathrm{mg} / \mathrm{kg})\end{array}$ \\
\hline $\begin{array}{c}\text { Vol. of gastric juice } \\
\text { (ml/100g) }\end{array}$ & $3.1 \pm 0.14$ & $2.6 \pm 0.21^{\mathbf{n}}$ & $1.6 \pm 0.14^{* * *}$ & $1.4 \pm 0.13^{* * *}$ \\
\hline $\begin{array}{c}\text { Free acidity } \\
\text { mEq/1/100mg }\end{array}$ & $29.2 \pm 0.62$ & $21.9 \pm 0.35^{* * *}$ & $15.8 \pm 0.39^{* * * *}$ & $14.6 \pm 0.28^{* * * *}$ \\
\hline $\begin{array}{c}\text { Total acidity } \\
\mathrm{mEq} / 100 \mathrm{mg}\end{array}$ & $68.4 \pm 1.42$ & $49.4 \pm 0.71^{* * *}$ & $43.7 \pm 0.44^{* * * *}$ & $42.6 \pm 0.65^{* * * *}$ \\
\hline Ulcer index & $1.0 \pm 0.02$ & $0.24 \pm 0.06^{* * *}$ & $0.09 \pm 0.01^{* * *}$ & $0.04 \pm 0.05^{* * *}$ \\
\hline
\end{tabular}

Volume of gastric juice, free acidity, total acidity, ulcer index in all the groups (n=6)

Values are mean $\pm S E M ; n=6$

(ANOVA followed by Tukey Kramer multiple comparison test)

$n s=$ Not significant, $* * *=p<0.001$

When compared with group A (Control),

(i) Reduction of volume of gastric juice was highly significant in group $C$ and group $D(p<0.001)$, while the reduction was not significant in Group B ( $>>0.05)$.

(ii) Reduction of free and total acidity was highly significant in Group B, Group C and group D ( $<<0.001)$.

(iii) Reduction of ulcer index was highly significant in Group B, Group C and group D ( $\mathrm{p}<0.001)$.

Comparing Group B with Group C and Group D,

(iv) Reduction of volume of gastric juice, free and total acidity was highly significant $(\mathrm{p}<0.001)$.

(v) Reduction of ulcer index was not significant ( $p>0.05)$ in Group C but significant $(\mathrm{p}<0.05)$ in Group D.

Comparing Group C with Group D

(vi) Reduction of volume of gastric juice, free and total acidity was not significant $(\mathrm{p}>0.05)$.

(vii) Reduction of ulcer index was not significant ( $\mathrm{p}>0.0$

Volume of gastric juice, free acidity, total acidity, ulcer index in all the groups $(n=6)$

\section{DISCUSSION:}

Plant extracts are some of the most attractive sources of new drugs and have shown promising results in the treatment of gastric ulcers. Several folk medicinal plants and herbs have been used to treat gastrointestinal disorders or gastric ulcer

It was found that oral administration of aqueous extract of cumin seeds markedly reduced aspirin induced gastric ulcer in rats, a convenient method of screening plant extracts for evaluation and cytoprotection in macroscopically and microscopically visible lesions. Animals pre-treated with cumin seed extract produced significant reduction $\mathrm{p}<0.001$ in ulcer index as established by measuring ulcer index, and further by histopathological findings. The cytoprotective effect of NS observed in the present study could be attributed to the endogenous generation of prostaglandins (PG), responsible for maintaining the cellular integrity of the gastric epithelium. ${ }^{14}$ It has been reported that plants and spices sometimes exhibit their cytoprotective action through their mild irritant property. This protection is called "adaptive cytoprotection. 15. This is supported by histopathological findings of our study. Pre-treatment with aqueous extract of NS prevented histopathological changes like congestion, haemorrhage, oedema, necrosis, inflammatory and dysplastic changes, erosions and ulceration caused by the destructive stimuli of aspirin in the gastric tissue. This cytoprotective ability of NS may be attributed to chemical components such as TQ, a major and active constituent of NS. ${ }^{16}$ In some earlier studies, TQ has been reported to exhibit a significant protective action on gastric mucosal lesions induced by different necrotic agents. ${ }^{17}$ Recent clinical and experimental studies have shown several therapeutic effects of Nigella sativa L (Rananculacene) (NS) extracts including its antioxidant, hepatoprotective, immunomodulatory, anti-inflammatory and anti-tumour activities. $^{18}$ The gastro-protective action was evaluated and the results of our study indicate that aqueous extract of $\mathrm{N}$. Sativa in doses $250 \mathrm{mg} / \mathrm{kg}$ and $500 \mathrm{mg} / \mathrm{kg}$ respectively reduced volume of gastric juice, free and total acidity and ulcer index in a highly significant manner when compared to control $(\mathrm{p}<0.001)$. When compared with positive control i.e. ranitidine $20 \mathrm{mg} / \mathrm{kg}$, N. Sativa in $500 \mathrm{mg} / \mathrm{kg}$ dose proved to be non inferior ( $\mathrm{p}>0.05$ ) while $\mathrm{N}$. sativa $250 \mathrm{mg} / \mathrm{kg}$ proved to be less effective than its higher dose and ranitidine $(\mathrm{p}<0.01)$. Our findings are in agreement with data reporting that an aqueous extract of NS did not only inhibit gastric secretion, free and total acidity but also reduced the ulcer index in rats. ${ }^{19} \mathrm{NS}$ extract was able to produce a significant reduction of the gastric mucosal damage induced by aspirin, indicating a probable local increase in PG synthesis. ${ }^{20}$ The results of the present study establish the gastro protective role of NS aqueous extract that substantiates its use against gastric disorders in traditional medicine.

To our knowledge, very few studies have evaluated the gastro protective effect of aqueous extract of NS. Considering aqueous extract of NS in $500 \mathrm{mg} / \mathrm{kg}$ dose to be comparable to Ranitidine $20 \mathrm{mg} / \mathrm{kg}$, the most widely prescribed $\mathrm{H}_{2}$ receptor blocker, further studies may be done to evaluate and establish the other possible underlying mechanism of gastro protective action of aqueous extract of NS. 


\section{REFERENCES:}

1. Alkofahi A, Atta AH. Pharmacological screening of the antiulcerogenic effects of some Jordanian Medicinal Plants in rats. J Ethnopharmacol. 1999; 65:341-5.

2. Peskar BM, Maricic N. Role of prostaglandins in gastroprotection. Dig Dis Sci. 1998;43:S23-

3. Al-Mofleh IA, Alhaider AA, Mossa JS, Al-Sohaibani MO, Rafatullah S, Qureshi S. Protection of gastric mucosal damage by Coriandrum sativum L. Pretreatment in Wistar albino rats. Environ Toxicol Pharmacol. 2006;22:64-9.

4. Arslan SO, Gelir E, Armutcu F, Coskun O, Gurel A, Sayan H, et al. The protective effect of thymoquinone on ethanol-induced acute gastric damage in the rats. Nutrit Res. 2005;25:673-80.s

5. Clark W.E, Extracta Liquida Pharmaceutical Formulations in: The Chemist and Druggist Book. Le G Editors11th Edition. London, $1950 ; 183$.

6. Alqasoumi S, Al-Sohaibani M, Al-Howiriny $\mathrm{T}$, Al-Yahya M, Rafatullah S. Rocket "Eruca sativa": A salad herb with potential gastric anti-ulcer activity. World J Gastroenterol 2009; 15(16): 1958-1965

7. Ghosh MN: toxicity studies, Fundamentals of Experimental pharmacology, $3^{\text {rd }}$ Edition, 2003:153-158

8. Shay H, Komarov Sa, Fels SS, Meravge D, Grvenstein M and Siplet h: A simplified method for the uniform production of gastric ulceration in the rats, Gastroenterology $1945 ;$; 5):43-6.

9. Sanyal AK, Debnath PK, Bhattacharya Sk, Gode KD .The effect of cyproheptadine on gastric activity-an experimental study. In: Pfeiffer CJ Ed.Peptic Ulcer.Copenhagen.Munksgaard,1971; p.312318

10. Kulkarni S K. Handbook of Experimental pharmacology. Vallabh Prakashan Delhi $3^{\text {rd }}$ Edition 2005:148-150.
11. Ganguly AK and Bhatnagar Op: Effects of bilateral adrenalectomy on the production of restraint ulcer in the stomach of albino rats. Can J Physiol Pharmacol 1973:51:748-750.

12. Banccroft JD, Stevens A. Theory and practice of histological techniques. $4^{\text {th }}$ ed. London: Churchill Livingstone; 1996.

13. Culling CF. Handbook of histopathological and histochemical techniques. 3rd ed. London: Butterworth and Co; 1974. p. 37.

14. Robert A, Nezamis JE, Lancaster C, Davis JP, Field SO, Hanchar AJ. Mild irritants prevent gastric necrosis through adaptive cytoprotection mediated by prostaglandins. Am J Physiol. 1983; 245:G113-G21.

15. Rafatullah S, Galal AM, Al-Yahya MA, Al-Said MS. Gastric antiulcer and cytoprotective effects of Aframomum melegueta in rats. Int J Pharmaco. 1995; 33:311-6.

16. Arslan SO, Gelir E, Armutcu F, Coskun O, Gurel A, Sayan H, et al. The protective effectof thymoquinone on ethanol-induced acute gastric damage in the rats. Nutrit Res.2005; 25:673-80.

17. Abdel-Fattah AM, Matsumoto K, Watanabe H. Antinociceptive effects of Nigella sativa oil and its major component, thymoquinone, in mice. Eur J Pharmacol. 2000; 400:89-97

18. Bahram Pourghassem-Gargari1, Vahideh Ebrahimzadeh-Attary, Maryam Rafraf and Abolfazl Gorbani. Effect of dietary supplementation with Nigella sativa L. Journal of Medicinal Plants Research Vol. 3(10), pp. 815-821, October, 2009

19. Akhtar MS, Riffat S. Field trial of Saussurea lappa roots against nematodes and NigellaSativa seeds against cestodes in children. J Pak Med Assoc. 1991; 41:185-7.

20. Burits M, Bucar F. Antioxidant activity of Nigella sativa essential oil. Phytother Res. 2000;14:323-8. 